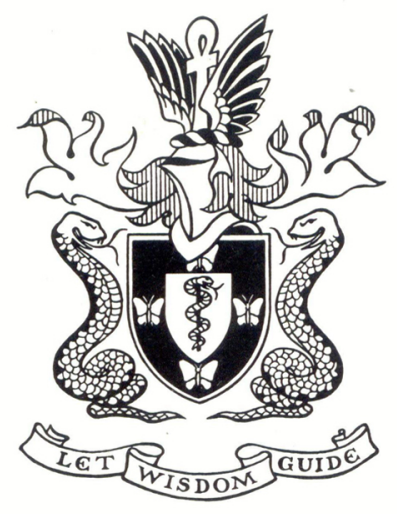

THE BRITISH JOURNAL OF PSYGHIATRY

December 1989

Vol 155

Supplement 8

\title{
SEROTONIN IN BEHAVIOURAL DISORDERS
}

Symposium of

XVIth Collegium Internationale

Neuro-psychopharmacologicum

Munich 15th-19th August, 1988

Edited by

Donald Eccleston and

Declan P. Doogan

Published by The Royal College of Psychiatrists 


\title{
THE BRITISH \\ JOURNAL OF PSYCHIATRY
}

\section{Serotonin in Behavioural Disorders}

Symposium of XVIth Collegium Internationale

Neuro-psychopharmacologicum, Munich 15th-19th August, 1988

Edited by

\author{
DONALD ECGLESTON \\ AND \\ DECLAN P. DOOGAN
}

The symposium was supported by a grant from Pfizer International 


\section{THE BRITISH \\ JOURNAL OF PSYCHIATRY}

Published monthly

Founded in 1853 as the Asylum Journal and known as the Journal of Mental Science from 1855 to 1963 .

\begin{tabular}{lcl} 
& \multicolumn{3}{c}{ EDITOR } & \\
& Hugh Freeman & \\
& ASSOCIATE EDITORS & \\
Dora Black & Alan Kerr & $\begin{array}{l}\text { Martin Roth } \\
\text { Sidney Crown }\end{array}$
\end{tabular}

ASSISTANT EDITORS

\begin{tabular}{|c|c|c|c|}
\hline $\begin{array}{l}\text { Alexander Kellam } \\
\text { Julian Leff } \\
\text { Catherine Oppenhe } \\
\text { Ian Pullen }\end{array}$ & mer & $\begin{array}{l}\text { Michael Reveley } \\
\text { Henry Rollin } \\
\text { Oliver Russell } \\
\text { Colin Shapiro }\end{array}$ & $\begin{array}{l}\text { George Stein } \\
\text { Digby Tantam } \\
\text { Greg Wilkinson } \\
\text { Stephen Wilson }\end{array}$ \\
\hline & & $\begin{array}{l}\text { ATIONS MANAGER } \\
\text { Jago }\end{array}$ & \\
\hline $\begin{array}{l}\text { SCIENTIFIC EDITOR } \\
\text { Ralph Footring }\end{array}$ & $\begin{array}{l}\text { EDI } \\
\text { Juc } \\
\text { Sar }\end{array}$ & $\begin{array}{l}\text { RIAL ASSISTANTS } \\
\text { Ashworth } \\
\text { Conyers }\end{array}$ & $\begin{array}{l}\text { BULLETIN MANAGER } \\
\text { Elaine Millen }\end{array}$ \\
\hline
\end{tabular}

Correspondence, manuscripts, books for review, for both the Journal and the Bulletin should be addressed to the Editor, 17 Belgrave Square, London SW1X 8PG (Tel 01-235 8857).

Advertising enquiries, correspondence and copy should be addressed to Mr Peter $\mathrm{T}$. Mell, Advertisement Manager, PTM Professional Publications Ltd, 282 High Street, Sutton, Surrey SM1 1PQ (Tel 01-642 0162).

Subscriptions for non-members of the College are payable to British Journal of Psychiatry Subscription Department, The Royal Society of Medicine, 1 Wimpole Street, London W1M 8AE. Queries from non-members about missing or faulty copies should be addressed within six months to the same address; similar queries from College members should be addressed to the Registration Department, The Royal College of Psychiatrists, 17 Belgrave Square, London SW1X 8PG.
Annual subscription rates 1990 (12 issues post free)
United Kingdom: Institutions $£ 105.00$; Individuals $£ 86.00$
United States: Institutions $\$ 265.00$; Individuals $\$ 162.00$
Elsewhere: Institutions $£ 132.00$; Individuals $£ 106.00$
Single copies of the Journal, $£ 10.00, \$ 20.00$ (post free)

US Mailing Agents: Expediters of the Printed Word Ltd, 527 Madison Avenue, Suite 1217, New York, NY 10022. 2nd Class postage paid at New York City, NY (USPS No. 536-870).

Back issues published before 1987 may be purchased from William Dawson \& Sons Ltd, Cannon House, Folkestone, Kent, England (Tel. 0303 850101).

Printed by Henry Ling Ltd, The Dorset Press, 23 High East Street, Dorchester, Dorset DT1 1HD (Tel. 0305 251066).

\section{(C) 1989 THE ROYAL COLLEGE OF PSYCHIATRISTS}




\section{Contents}

Introduction

D. ECCLESTON

Evidence for the 5-HT hypothesis of suicide: A review of post-mortem studies

J. J. MANN, V. ARANGO, P. M. MARZUK, S. THECCANAT and D. J. REIS

Obsessive-compulsive disorder as a 5-HT subsystem-related behavioural disorder

D. L. MURPHY, J. ZOHAR, C. BENKELFAT, M. T. PATO, T. A. PIGOTT and T. R. INSEL

Serotonergic dysfunction in depression

H. MELTZER

The antidepressant effects of 5-HT uptake inhibitors

A. ÅBERG-WISTEDT

Reduction of food intake by manipulation of central serotonin: Current experimental results

S. GARATTINI, T. MENNINI and R. SAMANIN

Central serotonin and impulsive aggression

E. F. COCCARO

Is there a relationship between serotonin receptor subtypes and selectivity of response in specific psychiatric illnesses?

S. H. MONTGOMERY and N. FINEBERG 